\title{
Pentingnya Penerapan Keselamatan dan Kesehatan kerja Perawat di IGD
}

\author{
Aruni Muharani \\ arunikisaran@gmail.com
}

\section{LATAR BELAKANG}

Perawat merupakan petugas kesehatan dengan presentasi terbesar dan memegang peranan penting dalam pemberian pelayanan kesehatan. Dalam menjalankan tugasnya perawat berisiko mengalami gangguan kesehatan dan keselamatan kerja (K3). Penelitian ini bertujuan untuk menganalisis risiko K3 pada perawat di instalasi gawat darurat (IGD). Pelaksanaan Keselamatan dan Kesehatan Kerja (K3) adalah salah satu bentuk upaya untuk menciptakan tempat kerja yang aman, sehat, dan bebas dari pencemaran lingkungan, sehingga dapat mengurangi dan atau bebas dari kecelakaan kerja dan penyakit akibat kerja yang pada akhirnya dapat meningkatkan efisiensi dan produktivitas kerja. Kecelakaan kerja tidak saja menimbulkan korban jiwa maupun kerugian materi bagi pekerja dan pengusaha, tetapi juga dapat mengganggu proses produksi secara menyeluruh, merusak lingkungan yang pada akhirnya akan berdampak pada masyarakat luas.

Menurut Undang-undang No. 44 Tahun 2009 Rumah Sakit adalah institusi pelayanan kesehatan bagi masyarakat dengan karakteristik tersendiri yang dipengaruhi oleh perkembangan ilmu pengetahuan kesehatan, kemajuan teknologi, dan kehidupan sosial ekonomi masyarakat yang harus tetap mampu meningkatkan pelayanan yang lebih bermutu dan terjangkau oleh masyarakat agar terwujud derajat kesehatan yang setinggi-tingginya. Dari pengertian tersebut, rumah sakit melakukan beberapa jenis pelayanan diantaranya pelayanan medik, pelayanan penunjang medik, pelayanan perawatan, pelayanan rehabilitasi, pencegahan dan peningkatan kesehatan, sebagai tempat pendidikan, pelatihan medik dan para medik, sebagai tempat penelitian, pengembangan ilmu dan teknologi bidang kesehatan. Selain dituntut mempu memberikan pelayanan dan pengobatan yang bermutu, Rumah Sakit juga dituntut harus melaksanakan dan mengembangkan program Kesehatan dan Keselamatan Kerja di Rumah Sakit (K3RS) seperti yang tercantum dalam buku Standar Pelayanan Rumah Sakit dan terdapat dalam instrumen akreditasi Rumah Sakit.

Dalam Undang-Undang Nomor 36 Tahun 2009 tentang Kesehatan, Pasal 165 : pengelola tempat kerja wajib melakukan segala bentuk upaya kesehatan melalui upaya pencegahan, 
peningkatan, pengobatan, dan pemulihan bagi tenaga kerja. Berdasarkan pasal tersebut maka pengelola tempat kerja di Rumah Sakit mempunyai kewajiban untuk menyehatkan para tenaga kerjanya. Salah satunya adalah melalui upaya kesehatan kerja disamping keselamatan kerja. Rumah Sakit harus menjamin kesehatan dan keselamatan baik terhadap pasien, penyedia layanan atau pekerja maupun masyarakat sekitar dari berbagai potensi bahaya di Rumah Sakit. Oleh karena itu, Rumah Sakit dituntut untuk melaksanakan Upaya Kesehatan dan Keselamatan Kerja (K3) yang dilaksanakan secara terintegrasi dan menyeluruh sehingga risiko terjadinya Penyakit Akibat Kerja (PAK) dan Kecelakaan Akibat Kerja (KAK) di Rumah Sakit dapat dihindari. Penyakit akibat kerja di rumah sakit dapat menyerang semua tenaga kerja baik medis maupun non medis Sehingga sasaran utama K3RS adalah tenaga medis, tenaga non medis, pasien, pengunjung / pengantar pasien, serta masyarakat sekitar Rumah Sakit.

Perawat merupakan petugas kesehatan dengan presentasi terbesar dan memegang peranan penting dalam pemberian pelayanan kesehatan. Dalam menjalankan tugasnya perawat berisiko mengalami gangguan kesehatan dan keselamatan kerja (K3). Penelitian ini bertujuan untuk menganalisis risiko K3 pada perawat di instalasi gawat darurat (IGD) dan kemampuan baik jasminah maupun rohani tenaga kerja pada khususnya dan manusia pada umumnya serta hasil karya dan budayanya. Dari segi keilmuaan diartikan sebagai suatu pengetahuan dan penerepannya dalam usaha mencegah kemungkinan terjadinya kecelakaan dan penyakit akibat kerja.

\section{METODE}

Metode penulisan ini menggunakan metode literature review dengan mengumpulkan bahan berupa artikel, jurnal dan buku yang erat kaitannya dengan pelaksaan keselamatan dan kesehatan kerja. Adapun jurnal, artikel serta buku yang digunakan pada penulisan ini didapat melalui e-book, Google Scholar, Jurnal Keperawatan Indonesia serta diambil dari search engineer seperti google.com. Literature Review ini menggunakan literatur terbitan tahun paling lama 2012 


\section{HASIL}

Berdasarkan hasil analisis dari beberapa jurnal dan kajian, didapat bahwa penerapan keselamatan dan kesehatan kerja (K3) adalah Perawat yang memiliki sikap negative terhadap pelaksanaan keselamatan dan kesehatan kerja cenderung berisiko 22 kali mengalami kecelakaan kerja dibandingkan perawat yang bersikap positif; perawat yang tidak mengikuti pelatihan kesehatan dan keselamatan kerja berisiko 5 kali mengalami kecelakaan kerja; perawat yang tidak lengkap mendapatkan sosialisasi promosi keselamatan dan kesehatan kerja berisiko 14 kali mengalami kejadian kecelakaan kerja. Kecelakaan kerja di IGD itu terjadi karena belum maksimalnya penerapan K3 di rumah sakit. Oleh karena itu,perlu diterapkan manajemen K3 untuk mengurangi angka kecelakaan kerja tersebut. Penerapan K3 mampu menunjang pelayanan kesehatan yang lebih baik.

\section{PEMBAHASAN}

Lingkungan Instalasi Gawat Darurat merupakan salah satu tantangan yang sangat berbahaya di Rumah Sakit, terutama karena lingkungannya yang tidak terstruktur dan tergesagesa, dengan pasien yang mengalami masalah yang tidak dapat diprediksi, dengan ukuran dan tingkat urgensi pasien yang bervariasi, dan pada waktu yang tidak terjadwal. Pelayanan pasien Gawat Darurat adalah pelayanan yang memerlukan pelayanan segera, yaitu cepat, tepatdan cermat untuk mencegah kematian dan kecacatan, pelayanan ini bersifat penting (emergency) sehingga diwajibkan untuk melayani pasien 24 jam sehari secara terus menerus (Destifiana, 2015)

.Lingkungan Instalasi Gawat Darurat merupakan salah satu tantangan yang sangat berbahaya di Rumah Sakit, terutama karena lingkungannya yang tidak terstruktur dan tergesa-gesa, dengan pasien yang mengalami masalah yang tidak dapat diprediksi, dengan ukuran dan tingkat urgensi pasien yang bervariasi, dan pada waktu yang tidak terjadwal.

\section{Pemeliharaan Kesehatan Petugas IGD}

Kesegaran jasmani dan rohani merupakan faktor penunjang untuk meningkatkan produktifitas seseorang dalm bekerja. Kesegaran tersebut dimulai sejak memasuki pekerjaan dan terus dipelihara selama bekerja, bahkan sampai setelah berhenti bekerja. Kesegaran jasmani dan rohani bukan saja pencerminan kesehatan fisik dan mental, tetapi merupakan gambaran adanya keserasian penyesuaian seseorang dengan pekerjaannya, yang sangat dipengaruhi oleh kemampuan, 
pengalaman, pendidikan dan pengetahuan yang dimiliki. Berdasarkan Buku Pedoman Penyelenggaraan Keselamatan Kerja, Kebakaran, dan Kewaspadaan Bencana di RS PKU Muhammadiyah Yogyakarta Tahun 2005 pemeliharaan kesehatan petugas Instalasi Gawat Darurat tidak ada penjelasan. Buku pedoman lebih menjelaskan kepada upaya pencegahan dan penanggulangan kebakaran tetapi rumah sakit khususnya Instalasi Gawat Darurat telah menerapkan pemeliharaan terhadap petugasnya.

Berdasarkan hasil penelitian mengenai program pemeliharaan kesehatan petugas Instalasi Gawat Darurat sejauh ini sudah dilaksanakan dengan baik oleh para petugas seperti halnya telah diuraikan bahwa sudah ada jaminan kesehatan terhadap para petugas dari rumah sakit tersebut, dan sudah dilakukan screening kesehatan tiap tahun untuk seluruh petugas Instalasi Gawat Darurat tersebut secara baik.

\section{Pemakaian Alat Pelindung Diri}

Berdasarkan Buku Pedoman Penyelenggaraan Keselamatan Kerja, 26 jurnal KESMAS UAD KES MAS ISSN : 1978-0575 Penerapan Manajemen Keselamatan dan Kesehatan Kerja.........(Puji Winarni Rahayuningsih) Page 31 Kebakaran dan Kewaspadaan Bencana di Rumah Sakit PKU Muhammadiyah Yogyakarta Tahun 2005 penggunaan alat pelindung diri diwajibkan untuk seluruh karyawan rumah sakit khususnya di Instalasi Gawat Darurat sebelum memulai melakukan pekerjaan. Alat pelindung diri yang ada di Instalasi Gawat Darurat seperti masker, kacamata, schout, handscoon, baju kerja, easy move wajib digunakan pada saat melakukan pemeriksaan terhadap pasien. Di Instalasi Gawat Darurat penggunaan alat pelindung diri hanya dilakukan untuk pemeriksaan yang beresiko seperti pemeriksaan pasien yang terpapar HIV, sedangkan untuk pemeriksaan yang ringan tidak digunakan. Balai K3 (2008), juga menjelaskan bahwa alat pelindung diri (APD) adalah seperangkat alat yang digunakan oleh tenaga kerja untuk melindungi seluruh atau sebagian tubuhnya terhadap kemungkinan adanya potensi bahaya atau kecelakaan kerja yang terjadi. APD juga dipakai sebagai upaya terakhir dalam usaha melindungi tenaga kerja apabila usaha rekayasa (engineering) dan administratif tidak dapat dilakukan dengan baik. Hasil penelitian menunjukkan bahwa penggunaan alat pelindung diri di Instalasi Gawat Darurat sudah dilaksanakan tetapi belum maksimal atau kurang disiplin digunakan pada waktu melakukan pekerjaan. Ketidakdisiplinan petugas Instalasi Gawat Darurat terhadap penggunaan alat pelindung diri disebabkan karena faktor kebiasaan petugasnya masing-masing. Penggunaan 
alat pelindung diri sudah baik digunakan. Berdasarkan Buku Pedoman Penyelenggaraan Keselamatan Kerja, Kebakaran, dan Kewaspadaan Bencana di Rumah Sakit PKU Muhammadiyah Yogyakarta Tahun 2005, seharusnya mewajibkan semua karyawan Rumah Sakit PKU Muhammadiyah Yogyakarta untuk memakai APD sesuai dengan kebutuhan unit kerjanya masingmasing sebelum memulai pekerjaan. Di Instalasi Gawat Darurat sendiri penggunaan alat pelindung diri seharusnya digunakan pada waktu melakukan tindakan atau pada pemeriksaan darurat tetapi hal ini selalu diabaikan oleh para petugas (faktor kebiasaan). Hal ini nantinya akan menyebabkan kemungkinan terjadinya bahaya penyakit akibat kerja atau kecelakaan kerja.

\section{Pencegahan Bahaya atau Kecelakaan Kerja}

Pencegahan bahaya atau kecelakaan kerja adalah keamanan petugas Instalasi Gawat darurat terhadap bahaya kecelakaan fisik yang terjadi selama pemeriksaan dan selama melakukan

pekerjaan. Semua petugas wajib mengikuti prosedur atau pedoman yang telah ditetapkan. Berdasarkan hasil penelitian, upaya pencegahan bahaya atau kecelakaan kerja yang terjadi di Instalasi Gawat Darurat antara lain:

a) Tersedianya alat pemadam kebakaran

b) Pelatihan penaggulangan bahaya kebakaran

c) Bed-bed pasien dilengkapi dengan pengaman

d) Pemeriksaan kesehatan secara berkala

e) Pemantauan aspek-aspek lingungan kerja seperti pengecekan suhu, kelembaban, pencahayaan ruangan, kebersihan ruangan-ruangan (toilet, tempat cuci alat-alat)

\section{Pemeriksaan Kesehatan Berkala}

Berdasarkan Buku Pedoman Penyelenggaraan Keselamatan Kerja, Kebakaran, dan Kewaspadaan Bencana di RS PKU Muhammadiyah Yogyakarta Tahun 2005 pemeriksaan kesehatan karyawan pada waktu-waktu tertentu terhadap karyawan yang dilakukan oleh dokter, meliputi pemeriksaan kesehatan sebelum bekerja, pemeriksaan kesehatan berkala, pemeriksaan kesehatan khusus dan pemeriksaan kesehatan penyakit umum. Untuk pemeriksaaan kesehatan berkala dilaksanakan setahun sekali yang dilakukan oleh TIM K3 Rumah Sakit, pemeriksaan di 
Instalasi Gawat Darurat meliputi ronsen paru, rekam jantung, dan tes darah lengkap. Secara umum pelaksanaan pemeriksaan kesehatan berkala di Instalasi Gawat Darurat sudah sesuai dengan Buku Pedoman Penyelenggaraan Keselamatan Kerja, Kebakaran, dan Kewaspadaan Bencana di Rumah Sakit PKU Muhammadiyah Yogyakarta Tahun 2005. Pemeriksaan disesuaikan menurut keperluan guna menilai kondisi kesehatan dan dibandingkan dengan hasil pemeriksaan kesehatan sebelumnya untuk mengetahui sejauh mana pekerjaan mempengaruhi kondisi kesehatan tenaga kerja.

\section{Pelatihan Keselamatan dan Kesehatan Kerja}

Berdasarkan Buku Pedoman Penyelenggaraan Keselamatan Kerja, Kebakaran, dan Kewaspadaan Bencana di RS PKU Muhammadiyah Yogyakarta Tahun 2005 tidak ada penjelasan mengenai pelatihan K3. Dalam buku pedoman dijelaskan lebih kepada upaya pencegahan dan penanggulangan kebakaran, tetapi rumah sakit mengadakan pelatihan K3 setiap satu tahun sekali. Pelatihan dilakukan pada unit kerja yang beresiko termasuk Instalasi Gawat Darurat. Petugas diberikan pelatihan setiap satu tahun sekali. Materi yang di dapatkan dalam pelatihan seperti pelatihan penanggulangan kebakaran, skill gawat darurat, PPGD (penanggulangan gawat darurat).

\section{PENUTUP}

Seluruh petugas Instalasi Gawat Darurat hendaknya melaksanakan program pemeliharaan kesehatan petugas IGD seperti screening tiap tahun, pemeriksaan hepatitis B, pemakaian alat pelindung diri, pencegahan bahaya atau kecelakaan kerja, pemeriksaan kesehatan berkala dan pelatihan tentang keselamatan dan kesehatan kerja agar petugas dalam kondisi yang aman, sehat, dan selamat selama bekerja di Instalasi Gawat Darurat. Seorang tenaga kesehatan atau perawat harus mengetahui tiga komponen K3 yaitu kapasitas kerja, beban kerja dan lingkungan kerja. Dan seorang perawat juga harus mengetahui Komitmen dan Kebijakan Komitmen diwujudkan dalam bentuk kebijakan (policy) tertulis, jelas dan mudah dimengerti serta diketahui oleh seluruh karyawan RS, agar tenaga kesehatan khususnya perawat terhindar dari risiko bahaya kerja di rumah sakit. 


\section{DAFTAR PUSTAKA}

Arrazy,S., dkk. (2014). Penerapan Sistem manajemen keselamatan kebakaran di rumah sakit dr. sobirin kabupaten musi rawas tahun 2013. Jurnal ilmu kesehatan masyarakat

Bawelle, S.C . (2013). Hubungan Penegtahuan dan Sikap Perawat dengan Pelaksanaan Keselamatan Pasien (Patient Safety) di Ruang Rawat Inap RSUD liun kendage tahune. E Journal Keperawatan, 01(01),1-7

Effendy. 2013. Strategi Pengembangan Sistem Manajemen K3 pada Rumah Sakit Umum Daerah Kayu agung Kabupaten Ogan Komering Ilir. JPFEBUNSOED, (online)3(1)

Hanifa, N. D., Respati, T., \& Susanti, Y. (2017). Hubungan Pengetahuan Dengan Upaya Penerapan K3 Pada Perawat. Artikel Penelitian, 1(1),1-6

Indrayani, P. (2016). Penerapan safety inspection sebagai upaya pencegahan kecelakaan kerja di PT. Multimas nabati asahan kuala tanjung tahun 2016 (Skripsi, Universitas Sumatera Utara).

Iskandar, E. (2017). Tata Kelola dan Kepatuhan Penerapan Standar Patient Safety Penyakit Stroke di Rumah Sakit Dr. Kanujoso Djatiwibowo Tahun 2015. Jurnal ARSI .3 (3):1-12

Keputusan Menteri Kesehatan Republik Indonesia Nomor 432/Menkes/SK/IV/2007 Tentang Pedoman Manajemen Kesehatan dan Keselamatan Kerja (K3) di Rumah Sakit.

Putri, O. Z., Mohammad, T., Hussin, A. B., \& Kasjono, H. S. (2017). Analisa Resiko keselamatan dan Kesehatan Kerja Pada Petugas Kesehatan Instalasi Gawat Darurat Rumah Sakit Akademika UGM. Jurnal Kesehatan, 10(1), 1-1

Ramdan, I. M., Rahma, A. (2017). Analisa Resiko Kesehatan dan Keselamatan Kerja (K3) Pada Perawat. JKD, 5(3), 229-241

Simamora, R. H. (2018). Buku ajar keselamatan pasien melalui timbang terima pasien berbasis komunikasi efektif: SBAR. Medan: USUpress.

Simamora, R. H. (2019). Buku ajar pelaksanaan identifikasi pasien. Uwais Inspirasi Indonesia. 
Salmawati, L., Rasul, M., \& Napirah, M. (2019). Faktor yang Berhubungan dengan Kejadian Kecelakaan Kerja Pada Perawat Di Ruang IGD RSU ANUTAPURA KOTA PALU. Jurnal Kesehatan Masyarakat 10(2), 104-112 
